\title{
Isolation of Mitochondria and Mitochondrial RNA from Crithidia fasciculata
}

\author{
By JOSIE M. NICHOLS* AND G. A. M. CROSS \\ M.R.C. Biochemical Parasitology Unit, University of Cambridge, \\ Molteno Institute, Downing Street, Cambridge CB2 $3 E E$
}

(Received I3 September 1976; revised I November 1976)

\begin{abstract}
SUMMARY
Two methods were used to isolate mitochondria from Crithidia fasciculata. In the first method, cells were weakened by exposure to hypotonic conditions and then disrupted by blending; mitochondria were subsequently isolated using disodium 3,5-diacetoamido-2,4,6-triiodobenzoate gradients. In the second, cells were treated with digitonin before disruption; mitochondria were purified by differential centrifugation. Both preparations were examined with the electron microscope and were also shown to possess several characteristic biochemical properties of mitochondria. Kinetoplast DNA was present in the mitochondria, uncontaminated by nuclear DNA.

Analysis by polyacrylamide gel electrophoresis showed two RNA components of molecular weights $0.47 \times 10^{8}$ and $0.22 \times 10^{6}$, in addition to cytoplasmic RNA contamination. Four mitochondrial components with sedimentation coefficients of $14.6 \mathrm{~S}, \mathrm{II} \cdot 4 \mathrm{~S}$, I0.1S and $6.9 \mathrm{~S}$ were identified on sucrose density gradients. Ethidium bromide abolished the incorporation of $\left[5^{-3} \mathrm{H}\right]$ uridine into the presumed mitochondrial RNA.
\end{abstract}

\section{INTRODUCTION}

Members of the protozoan order Kinetoplastida, which includes the genera Crithidia, Leishmania and Trypanosoma, are believed to contain a single mitochondrion (Paulin, 1975). If this mitochondrion is equivalent to mitochondria in other organisms, it should contain DNA coding for specific mitochondrial RNA and protein. The kinetoplast is composed of DNA (Bresslau \& Scremin, 1924; Steinert, Firket \& Steinert, 1958) and is a modified region of the single mitochondrion (Steinert, 1960).

The function of kinetoplast DNA (K-DNA) is unknown, although its presence or absence may be coupled to the proliferation and regression of functional mitochondria (Simpson, I972). Verification of the presence of RNA encoded by K-DNA in the mitochondrion would give support for K-DNA functioning as mitochondrial DNA. We decided to approach the problem by isolating mitochondria from Crithidia fasciculata, this species being chosen because of its relative ease of culture. However, the existence of a single mitochondrion consisting of several tubular extensions makes it difficult to isolate an intact mitochondrion, especially as the kinetoplastid flagellates are relatively resistant to cell breakage by standard methods (Simpson, $1968 ; 1972$ ). Several techniques have previously been used to accomplish this (Hill \& White, 1968; Renger \& Wolstenholme, 1970; Renger \& Wolstenholme, 1972; Kusel \& Storey, 1972; Toner \& Weber, 1972; Braly, Simpson \& Kretzer, 1974).

This paper describes the isolation of mitochondria, mitochondrial RNA and mitochondrial (kinetoplast) DNA from C. fasciculata.

* Present address: Biochemistry Department, University of Liverpool, P.O. Box 147, Liverpool L69 3BX. 


\section{METHODS}

Materials. Ethidium bromide was obtained from Boots Pure Drug Co., Nottingham; and actinomycin D, bovine serum albumin (fraction V), ribonuclease $A$, deoxyribonuclease $I$, MOPS [3-( $N$-morpholino)propanesulphonic acid], digitonin, and diethylpyrocarbonate from Sigma. Pronase was obtained from Calbiochem; $\left[5^{-3} \mathrm{H}\right]$ uridine $\left(5^{\circ} \circ \mathrm{Ci} \mathrm{mmol}^{-1}\right)$ from The Radiochemical Centre, Amersham; NADP from Boehringer; lithium dodecyl sulphate from Searle; Renografin (disodium 3,5-diacetoamido-2,4,6-triiodobenzoate) from Winthrop Laboratories, Surbiton-upon-Thames, Surrey; and Spurr resin from Agar-Aids, Bishop's Stortford, Hertfordshire. Other chemicals were obtained in analytical grades wherever possible.

Cultivation of organisms. Crithidia fasciculata was grown axenically in defined medium (Kidder \& Dutta, I958). Batch cultures $(500 \mathrm{ml})$ were harvested in the mid-exponential phase $\left(3 \times 10^{7}\right.$ to $4 \times 10^{7}$ cells $\left.\mathrm{ml}^{-1}\right)$ to prepare total cell RNA, and in the late-exponential phase $\left(8 \times 10^{7}\right.$ to $9 \times 10^{7}$ cells $\left.\mathrm{ml}^{-1}\right)$ to prepare mitochondria.

Escherichia coli (strain MRE600) was obtained as a frozen cake from the Microbiological Research Establishment, Porton Down, Wiltshire, and was stored at $-20^{\circ} \mathrm{C}$.

\section{Isolation of mitochondria}

Method I: hypotonic swelling and purification by Renografin gradients. The cells were harvested by centrifuging at $4000 \mathrm{~g}$ for $5 \mathrm{~min}$ at $4{ }^{\circ} \mathrm{C}$, washed twice with and resuspended (at $5 \times 10^{8}$ cells $\mathrm{ml}^{-1}$ ) in $2 \mathrm{~mm}$-EDTA $/ 2 \mathrm{mM}$-Tris/HCl buffer prepared in double-distilled water and adjusted to $\mathrm{pH} 8.0$ at $4{ }^{\circ} \mathrm{C}$. After about $30 \mathrm{~min}$, when the cells had swollen and assumed a spherical shape, the cells were disrupted in an MSE homogenizer for $2.5 \mathrm{~min}$ at full speed; 80 to $90 \%$ rupture was achieved. Mitochondria were released as swollen vesicles, some of which contained kinetoplasts. Immediately after disruption, a concentrated sucrose solution was added to the lysate to give a final concentration of $0.25 \mathrm{M}$. Swelling of the cells and the extent of breakage were routinely monitored by phase contrast microscopy.

The mitochondria were purified on Renografin gradients using the method of Braly et al. (1974). The gradients were centrifuged for $2 \mathrm{~h}$ at $77500 \mathrm{~g}$ in a Beckman SW 40 rotor at $4{ }^{\circ} \mathrm{C}$.

Method 2: treatment with digitonin and purification by differential centrifugation. The method used was that of Kusel \& Storey (1972) except that the cells were disrupted in an MSE homogenizer for I min at full speed. Cell rupture was always greater than $80 \%$.

Electron microscopy. Samples were fixed in $2.5 \%(\mathrm{v} / \mathrm{v})$ glutaraldehyde in $0.25 \mathrm{M}$-sucrose/ $0.2 \mathrm{M}$-cacodylate buffer $\mathrm{pH} 7.2$ for $\mathrm{I}$ to $2 \mathrm{~h}$ at $4{ }^{\circ} \mathrm{C}$, washed at $4{ }^{\circ} \mathrm{C}$ in the same buffer for I $5 \mathrm{~min}$ and for a second time overnight. They were then embedded in $2 \%(\mathrm{w} / \mathrm{v})$ Difco Bacto-agar in sucrose/cacodylate buffer and cut up into small pieces which were washed $(4 \times 15 \mathrm{~min})$ in sucrose/cacodylate buffer. Samples were then postfixed with $2 \%(\mathrm{w} / \mathrm{v})$ osmium tetroxide in $0.2 \mathrm{M}$-cacodylate for $\mathrm{I} \mathrm{h}$ at $0^{\circ} \mathrm{C}$, dehydrated in a graded series of ethanol/water mixtures, infiltrated with Spurr resin, and finally embedded in fresh Spurr resin (I $\mathrm{h}$ at $100^{\circ} \mathrm{C}$ ). Samples were sectioned on an LKB Ultratome III and collected on uncoated copper grids. Sections were stained for $15 \mathrm{~min}$ in a saturated solution of uranyl acetate in $50 \%$ ethanol and for 10 min in lead citrate before examination in a Philips EM30o electron microscope.

Extraction of RNA. RNA was extracted from cells and organelles by the method of Kirby 
(1965) and Parish \& Kirby (1966) as modified by Loening (1969). The RNA concentration was estimated by assuming an $E_{1 \mathrm{~cm}}^{1 \%}$ at $260 \mathrm{~nm}$ of 250 .

Polyacrylamide gel electrophoresis of RNA. Samples of RNA (5 to $20 \mu \mathrm{g}$ ) were analysed by polyacrylamide gel electrophoresis (Loening, 1967$)$ using $2.6 \%$ (w/v) gels at $8{ }^{\circ} \mathrm{C}$. rRNA of E. coli (mol. wts $1.07 \times 10^{6}$ and $0.56 \times 10^{6}$; Loening, 1967) was used as marker. The buffer (pH 7.8) contained: $40 \mathrm{~mm}$-Tris; $20 \mathrm{~mm}$-sodium acetate; and I mM-EDTA. Gels were scanned at $265 \mathrm{~nm}$ in a Joyce-Loebl ultraviolet scanner.

Sucrose density gradient centrifugation of RNA. RNA (20 to $60 \mu \mathrm{g}$ ) in $0.15 \mathrm{M}$-sodium acetate, $\mathrm{pH} 6.0$, containing $0.5 \%$ (w/v) lithium dodecyl sulphate, was layered on to $12 \mathrm{ml}$ I5 to $30 \%(\mathrm{w} / \mathrm{v})$ linear sucrose gradients prepared in $20 \mathrm{~mm}$-sodium acetate/ $\mathrm{r}$ mM-EDTA/ $40 \mathrm{mM}-\mathrm{Tris} / \mathrm{HCl}$ buffer, $\mathrm{pH} 7.8$, containing $0.5 \%$ lithium dodecyl sulphate, and centrifuged at 40000 rev. $\min ^{-1}$ for $16 \mathrm{~h}$ at $4{ }^{\circ} \mathrm{C}$, in the Beckman SW 40 rotor. rRNA of $E$. coli was used for calibration. The gradients were fractionated, and the absorbance was continuously measured at $254 \mathrm{~nm}$ using an ISCO density gradient fractionator model I83, equipped with an ISCO type 6 optical unit and model UA-5 absorbance monitor.

DNA analysis. Cells at $\left(\mathrm{I}^{8} \mathrm{ml}^{-1}\right)$ or organelles were lysed in $0 \cdot \mathrm{I} \mathrm{M}-\mathrm{NaCl} / \mathrm{O} \cdot 0 \mathrm{I} \mathrm{M}-\mathrm{EDTA} /$ I mM-Tris/ $\mathrm{HCl}$ buffer, $\mathrm{pH} 8.0$, containing $\mathrm{I} \%(\mathrm{w} / \mathrm{v})$ sodium dodecyl sulphate and I $\mathrm{mg}$ pronase $\mathrm{ml}^{-1}$ at $37^{\circ} \mathrm{C}$ for $2 \mathrm{~h}$. Digests were dialysed for $16 \mathrm{~h}$ at $4{ }^{\circ} \mathrm{C}$ against $0 . \mathrm{I} \mathrm{M}-\mathrm{NaCl} /$ $0.01 \mathrm{M}-\mathrm{EDTA} / \mathrm{I} \mathrm{mM}$-Tris/HCl buffer, $\mathrm{pH} 8.0$, and the precipitated dodecyl sulphate was removed by centrifugation. The clear supernatant was stored at $4{ }^{\circ} \mathrm{C}$ until required.

Analytical $\mathrm{CsCl}$ centrifugation was performed in a Beckman model $\mathrm{E}$ ultracentrifuge at $140700 \mathrm{~g}$ (44000 rev. $\mathrm{min}^{-1}$ ) at $20^{\circ} \mathrm{C}$ for $\mathrm{I} 6$ to $\mathrm{I} 8 \mathrm{~h}$ (Schildkraut, Marmur \& Doty, I962). Ultraviolet absorption photographs of the DNA distribution at equilibrium were scanned using a Joyce-Loebl recording microdensitometer. Buoyant densities were calculated using Micrococcus luteus DNA (I-73I $\left.\mathrm{ml}^{-1}\right)$ as marker (Szybalski, 1968).

Enzyme assays. Succinate dehydrogenase (succinate:(acceptor) oxidoreductase; EC I.3.99. I) activity was assayed by the method of King (1967). Glucose-6-phosphate dehydrogenase (EC I. I I . 49) activity was assayed by the method of Langdon (I966).

Protein was determined by the method of Lowry et al. (195I) using bovine serum albumin as the standard. Equivalent amounts of buffer were included in the blank when necessary.

\section{RESULTS}

\section{Properties of the mitochondrial preparations}

After centrifugation in Renografin gradients (method $\mathrm{I}$ ), two bands could usually be seen by eye, although the size of the upper band, containing membrane fragments and flagella in addition to mitochondria, was very variable. The lower band, at a density of $\mathrm{I} \cdot 18 \mathrm{~g} \mathrm{ml}^{-1}$, contained mitochondria with little cell debris and no whole cells (Fig. I $a$ ). Smaller mitochondria, of $0.5 \mu \mathrm{m}$ diameter, had a condensed matrix and large intracristal spaces, whereas larger mitochondria, some having a diameter of over $\mathrm{x} \cdot 0 \mu \mathrm{m}$, had a less electron-dense matrix and smaller intracristal spaces. Some mitochondria contained a section through a kinetoplast. The existence of various densities in the matrices could represent various degrees of leakiness of the mitochondria. Absorbance at $600 \mathrm{~nm}$ was used to follow the distribution of light-scattering material in the gradients; the distribution of protein and succinate dehydrogenase activity coincided with the material at $\mathrm{I} \cdot \mathrm{I} 8 \mathrm{~g} \mathrm{ml}^{-1}$, with the peak activity being $57 \mathrm{nmol} \mathrm{succinate} \mathrm{oxidized} \mathrm{min}^{-1}$ (mg protein) ${ }^{-1}$. Analysis by $\mathrm{CsCl}$ equilibrium centrifugation showed a fast-banding DNA component in the mitochondrial lysates, which is a characteristic of kinetoplast DNA (Dubuy, Mattern \& Riley, 1965). At equilibrium 

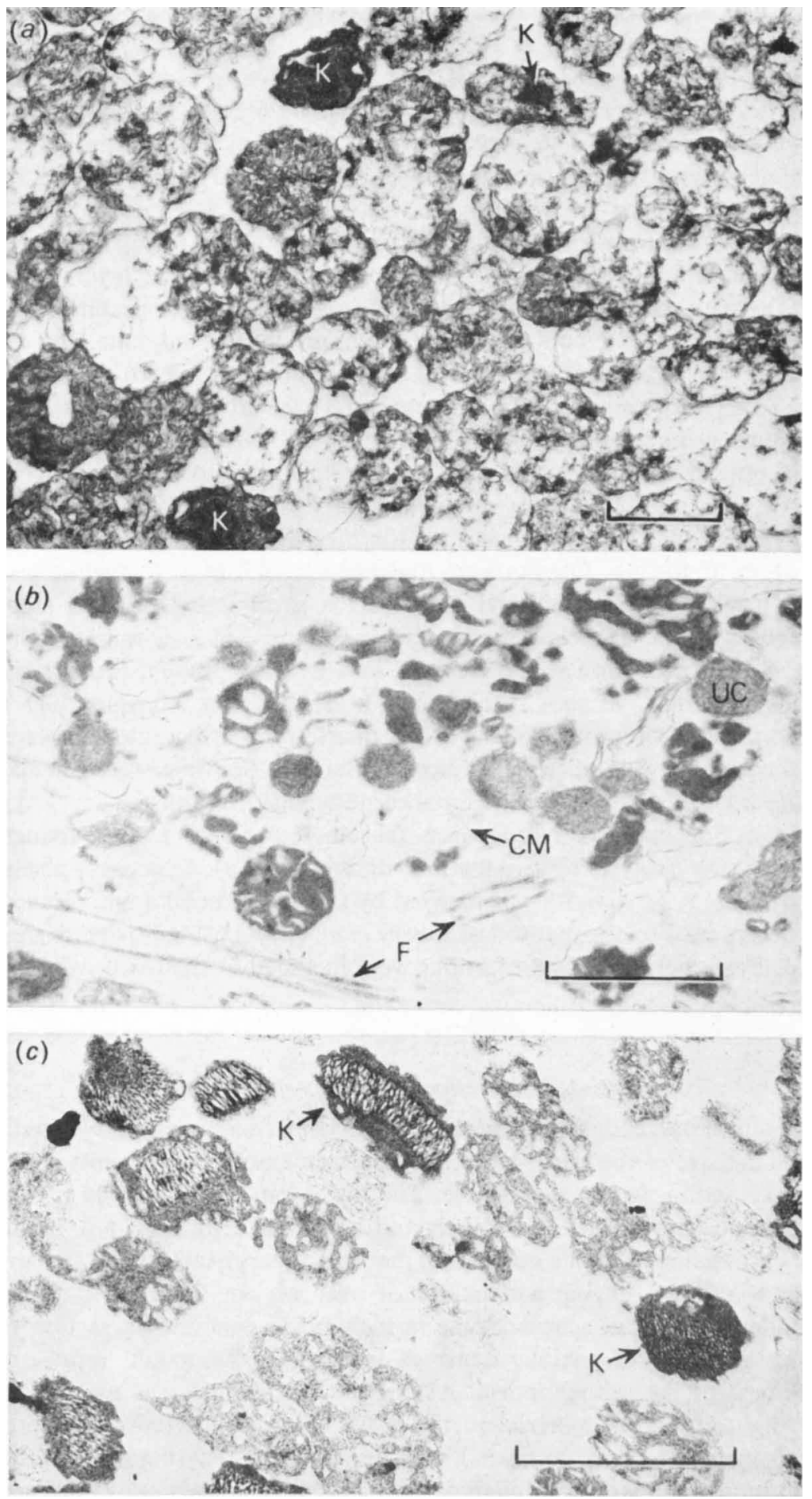

Fig. I. Electron micrographs of mitochondria isolated from $C$. fasciculata. (a) Mitochondria obtained by hypotonic swelling and disruption in an MSE homogenizer. Purification was by flotation on a Renografin gradient. (b) Mitochondria obtained by treatment with digitonin and disruption in an MSE homogenizer. Purification was by differential centrifugation. (c) Mitochondria obtained as for $(b)$. Purification was by flotation on a Renografin gradient. K, Kinetoplast DNA; F, flagella; CM, cell membrane; UC, unidentified component. Bar markers represent I $\mu \mathrm{m}$. 


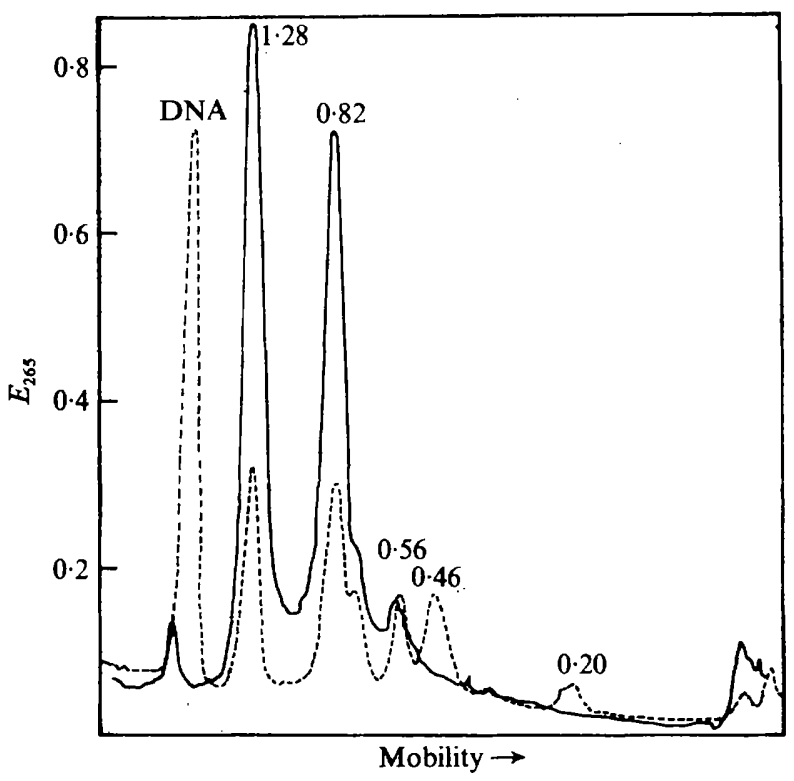

Fig. 2. Ultraviolet scans of RNA extracted from whole cells and mitochondria and analysed by polyacrylamide gel electrophoresis. Electrophoresis was performed in acetate buffer at $8^{\circ} \mathrm{C}$ for $2.5 \mathrm{~h}$. RNA molecular weights were determined relative to $E$. coli rRNA (mol. wts $1.07 \times 10^{8}$ and $0.56 \times 10^{6}$ ) run as an internal marker in duplicate gels. -, Total rRNA extracted from C. fasciculata (load $10 \mu \mathrm{g}) ;-.-$, RNA extracted from mitochondria.

(I $8 \mathrm{~h}$ ) there was only one component of buoyant density $\mathrm{I} \cdot 703 \mathrm{~g} \mathrm{ml}^{-1}$, which was identified as kinetoplast DNA. Nuclear DNA $\left(\mathrm{I} \cdot 717 \mathrm{~g} \mathrm{ml}^{-1}\right)$ was absent from all such mitochondrial preparations.

The final mitochondrial pellet prepared by method 2 (Fig. I $b$ ) was less pure than preparations obtained by Renografin centrifugation. Many flagella and cell membranes were present. The mitochondria were of a more uniform size than Renografin preparations and were all of approximately $0.5 \mu \mathrm{m}$ diameter. The matrix was electron dense with large intracristal spaces. The smaller mitochondria obtained by this method may be due to the isolation medium being isotonic at all stages of the preparation, whereas in those preparations involving hypotonic swelling, the mitochondria may have been damaged and become swollen. Succinate dehydrogenase activity was determined during the purification of mitochondria and in two different preparations the specific activity of the final mitochondrial pellet had increased to 2.5 times and 6 times that of the broken-cell homogenate. Glucose6-phosphate dehydrogenase is an enzyme of the pentose phosphate pathway which is generally considered to be cytoplasmic and occurs in trypanosomes (Mancilla \& Náquira, I964). Glucose-6-phosphate dehydrogenase activity was detected in extracts of sonicated C. fasciculata and its specific activity was monitored during the purification of mitochondria. Only $\mathrm{I}$ to $5 \%$ of the activity of the initial homogenate was found in the final mitochondrial preparations.

The best mitochondrial preparations (Fig. I c) were obtained by a combination of digitonin treatment and Renografin centrifugation. 


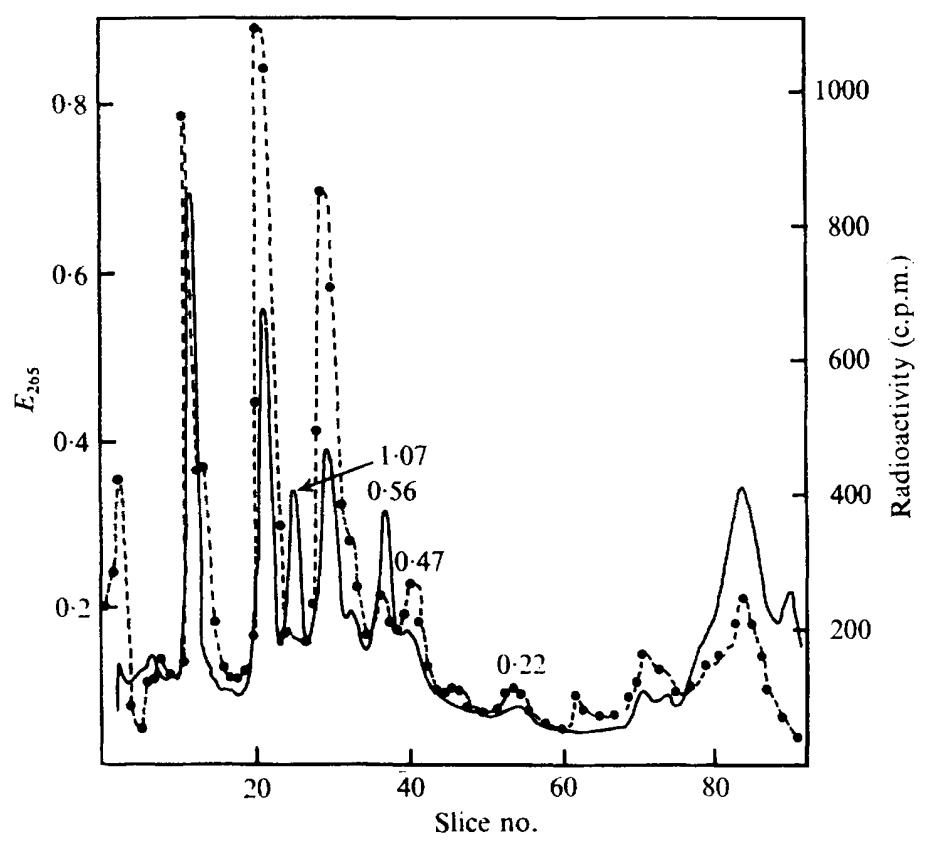

Fig. 3. Incorporation of $\left[5^{-2} \mathrm{H}\right]$ uridine into RNA extracted from mitochondria of $C$. fasciculata grown for $\mathrm{I}^{-} 5$ generations in the presence of $\left[5^{-}{ }^{8} \mathrm{H}\right]$ uridine $\left(2 \mu \mathrm{M}, 500 \mathrm{mCi} \mathrm{mmol}^{-1}\right)$. Electrophoresis was performed in acetate buffer at $8^{\circ} \mathrm{C}$ for $2 \cdot 75 \mathrm{~h}$. rRNA $(2 \mu \mathrm{g})$ of $E$. coli was included as marker. The gels were cut into $1 \mathrm{~mm}$ slices with a Mickle gel slicer and, after drying and digestion with $\mathrm{H}_{2} \mathrm{O}_{2}$, the radioactivity in the slices was determined in Triton/toluene scintillant. - . Absorbance at $265 \mathrm{~nm} ;---$, radioactivity.

Analysis of mitochondrial RNA by polyacrylamide gel electrophoresis

RNA species present in mitochondria, especially rRNA, are distinct from their cytoplasmic counterparts (Borst, 1972), and it was hoped that this would also apply in the case of mitochondrial RNA from $C$. fasciculata. However, it was first necessary to identify cytoplasmic RNA.

rRNA extracted from $C$. fasciculata and analysed by polyacrylamide gel electrophoresis consisted of two major components with molecular weights (relative to $E$. coli rRNA) of $1.28 \times 10^{6}$ and $0.82 \times 10^{6}$ (Fig. 2). Two minor components with molecular weights 0 o.71 $\times$ $10^{6}$ and $0.56 \times 10^{6}$ are believed to be breakdown products of the larger rRNA species, due to a 'hidden' break in the molecule (Pace, 1973) as in Crithidia oncopelti (Spencer \& Cross, 1976) and Crithidia luciliae (Reijnders et al., 1973). The small high molecular weight peak in the position expected for DNA (Loening, 1967) was absent after DNAase treatment of the sample.

RNA extracted from mitochondria prepared by digitonin treatment and differential centrifugation had two additional components (Fig. 2); their average molecular weights were calculated to be $0.47 \times 10^{6}$ and $0.22 \times 10^{6}$ (corresponding to sedimentation coefficients of $14.5 \mathrm{~S}$ and $9.5 \mathrm{~S}$ ). The amount of contamination by cytoplasmic RNA varied from 45 to $63 \%$. Treatment of samples with DNAase or RNAase confirmed that all components were RNA except for that of the highest molecular weight band which was DNA.

Incorporation of $\left[5^{-3} \mathrm{H}\right]$ uridine into growing cells [for $1 \cdot 5$ generations in the presence of I $\mu \mathrm{Ci} \mathrm{ml}^{-1}\left[5^{-3} \mathrm{H}\right]$ uridine $\left.\left(2 \mu \mathrm{M}, 500 \mathrm{mCi} \mathrm{mmol}^{-1}\right)\right]$ gave mitochondrial RNA components of 


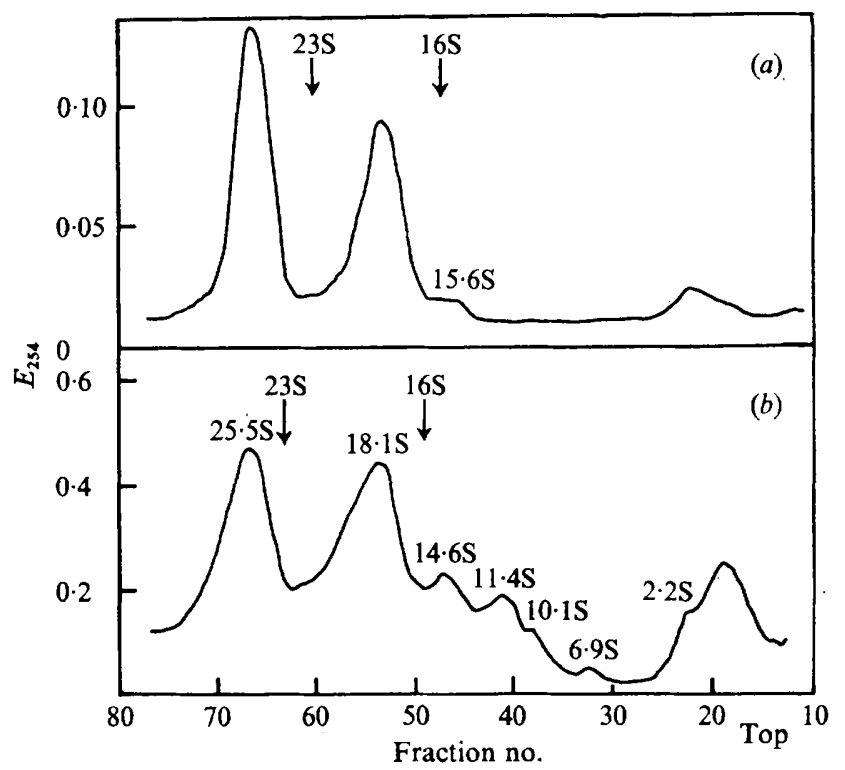

Fig. 4. Sucrose density gradient analysis of (a) total rRNA (20 $\mu \mathrm{g})$ from C. fasciculata and (b) RNA isolated from mitochondria. The RNA was analysed at $4{ }^{\circ} \mathrm{C}$ for $16 \mathrm{~h}$ in $\mathrm{I2} \mathrm{ml} \mathrm{m} 5$ to $30 \%$ sucrose gradients in $20 \mathrm{~mm}$-sodium acetate/1 mM-EDTA/40 mM-Tris/HCl buffer, $\mathrm{pH} 7.8$, containing $0.5 \%$ (w/v) lithium dodecyl sulphate. RNA sedimentation coefficients were determined relative to $E$. coli rRNA run in duplicate gradients.

the same specific activity as the cytoplasmic components (Fig. 3). Additional small radioactive peaks were detected which had not previously been detected by absorbance alone. These were not investigated further. Only $0.07 \%$ of incorporated $\left[5-{ }^{-} \mathrm{H}\right]$ uridine was recovered in the final mitochondrial preparation. Allowing for the estimated recovery of mitochondria this suggests that mitochondrial RNA represents about $\mathrm{x} \%$ of total cellular RNA.

RNA could not be detected in mitochondria purified on Renografin gradients. Addition of diethylpyrocarbonate, an RNAase inhibitor, was without effect. This result was disappointing since these mitochondrial preparations were of greater purity.

\section{Selective inhibition of cytoplasmic mitochondrial RNA synthesis}

The effects of two RNA inhibitors were investigated: actinomycin $D$, which preferentially inhibits cytoplasmic RNA synthesis (Vesco \& Penman, 1969); and ethidium bromide, an inhibitor of mitochondrial RNA synthesis (Attardi et al., 1970).

Actinomycin D was required at $50 \mu \mathrm{g} \mathrm{ml}^{-1}$ to inhibit the incorporation of $\left[5^{-3} \mathrm{H}\right]$ uridine into the total cell RNA of $C$. fasciculata by $97 \%$. This is much greater than the concentration required to inhibit mammalian RNA synthesis (approximately $0.04 \mu \mathrm{g} \mathrm{ml}^{-1}$ ) suggesting that $C$. fasciculata may be relatively impermeable to the drug. Ethidium bromide at $2 \mu \mathrm{g} \mathrm{ml}^{-1}$ gave no detectable inhibition of total RNA synthesis, as would be expected if it were only inhibiting mitochondrial RNA synthesis. Higher concentrations of drug $\left(20 \mu \mathrm{g} \mathrm{ml}^{-1}\right.$ and 40 $\left.\mu \mathrm{g} \mathrm{ml}^{-1}\right)$ inhibited the incorporation of $\left[5^{-3} \mathrm{H}\right]$ uridine into RNA by $12 \%$ and $45 \%$, respectively.

The effect of these drugs on individual RNA components was investigated, the RNA being analysed by sucrose density gradient centrifugation since it was occasionally found that RNA isolated from mitochondrial preparations would not enter polyacrylamide gels 


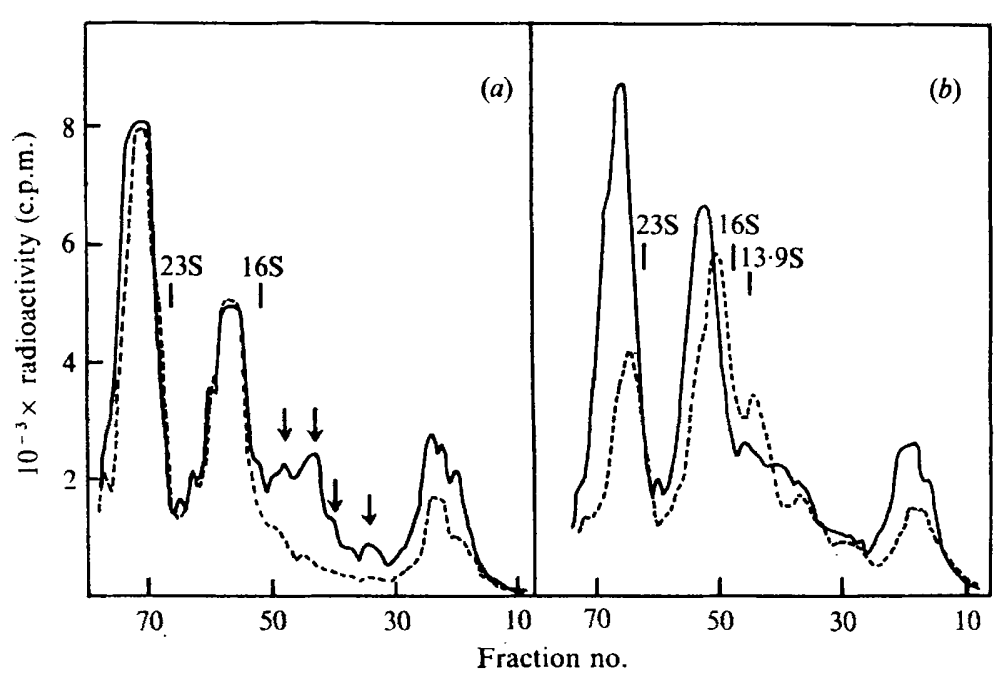

Fig. 5. Sucrose density gradient analysis of RNA isolated from mitochondria of $C$. fasciculata labelled with $\left[5^{-} \mathrm{H}\right]$ uridine in the presence and absence of $(a)$ ethidium bromide and $(b)$ actinomycin D. Crithidia fasciculata was grown to a density of $5 \times 10^{7}$ to $6 \times 10^{7}$ cells $\mathrm{ml}^{-1}$ before adding ethidium bromide (10 $\left.\mu \mathrm{g} \mathrm{ml}^{-1}\right)$ or actinomycin $\mathrm{D}\left(25 \mu \mathrm{g} \mathrm{ml}^{-1}\right)$ and, $30 \mathrm{~min}$ later, [5- ${ }^{3} \mathrm{H}$ ] uridine $(2 \mu \mathrm{M}, 500 \mathrm{mCi}$ $\mathrm{mmol}^{-1}$ ). The cells were harvested $3 \mathrm{~h}$ later. Conditions for centrifugation were as for Fig. 4. Arrows indicate species of RNA believed to be of mitochondrial origin. - - Control; - - -, in the presence of $(a)$ ethidium bromide or $(b)$ actinomycin $D$.

(possibly due to the presence of large amounts of K-DNA or protein). RNA isolated from mitochondria (Fig. $4 b$ ) contained four components of $14 \cdot 6 \mathrm{~S}, 1 \mathrm{I} \cdot 4 \mathrm{~S}$, $10 \cdot \mathrm{IS}$ and $6.9 \mathrm{~S}$, in addition to cytoplasmic contaminants. Ethidium bromide $\left(10 \mu \mathrm{g} \mathrm{ml}^{-1}\right)$ altered the radioactive profile of RNA isolated from mitochondria from cells labelled with $\left[5^{-3} \mathrm{H}\right]$ uridine (Fig. 5a). Synthesis of the presumptive mitochondrial components was abolished, whereas incorporation of $\left[5^{-} \mathrm{H}\right]$ uridine into the cytoplasmic contaminants was unaffected. Although the total incorporation of $\left[5^{-3} \mathrm{H}\right]$ uridine into the cytoplasmic components was not reduced substantially by actinomycin $D$, the large rRNA component was very much decreased compared with the control (i.e. the ratio of large rRNA to small rRNA decreased) and there was a concomitant increase in the breakdown product at $13.9 \mathrm{~S}$ (Fig. 5 ). There was no definitive effect upon the synthesis of the mitochondrial RNA components.

\section{DISCUSSION}

Previous attempts to isolate mitochondria from kinetoplastid flagellates usually involved vigorous disruption which probably caused extensive fragmentation of mitochondria. Two methods are described here. Preparations obtained by method I were morphologically pure; intact cells, flagella and cell membranes were absent. Mitochondria prepared by method 2 were accompanied by flagella and cell membranes.

There is no definitive evidence that these mitochondrial preparations represent whole mitochondria. If they do, each mitochondrion should contain a kinetoplast, but this would not be observed in a thin section. Braly et al. (1974) calculated that in any one thin section of Leishmania tarentolae mitochondria, the probability of sectioning the K-DNA of any kinetoplast-mitochondrion complex was $24 \%$. In this work $19 \%$ of the mitochondria in the 
electron micrographs contained a section through K-DNA. Therefore, it seems likely that each mitochondrial profile represents a whole mitochondrion.

There is some earlier evidence that kinetoplasts contain RNA. In 1969, Kallinikova stated that the kinetoplast of Trypanosoma cruzi contained RNA, although no experimental evidence was given. Steinert $e$ t al. (1969) showed by autoradiography and pulse labelling with $\left[{ }^{3} \mathrm{H}\right]$ uridine that the kinetoplast was a site of RNA synthesis. However, our studies (Fig. 3) suggest that K-DNA may be labelled by $\left[{ }^{3} \mathrm{H}\right]$ uridine. Autoradiography, coupled with enzymic digestion was used by Ozeki et al. (1971) to show that the kinetoplasts of $T$. cruzi and T. gambiense contained DNA, RNA and protein. More recently, Simpson (1973) demonstrated two RNA species, isolated from mitochondria of $L$. tarentolae, with sedimentation coefficients of $9 \mathrm{~S}$ and $12 \mathrm{~S}$. The synthesis of these RNA molecules was inhibited by ethidium bromide. These RNA components accounted for less than $2 \%$ of the total cell RNA and Simpson \& Lasky (1975) proposed that they represent stable mitochondrial mRNAs. We found RNA in mitochondria represented approximately $1 \%$ of total cell RNA. The sizes of these components are similar to those obtained by Simpson (1973).

The presence of RNA in the mitochondria supports the hypothesis that kinetoplast DNA may be transcribed, but hybridization studies are required to confirm the relationship between the numerous molecular species that have been identified in K-DNA (see, for example, Simpson, 1972; Renger \& Wolstenholme, 1970, 1972; Steinert \& Van Assel, 1975) and the isolated RNA. This should also determine which molecular species represents the true mitochondrial DNA.

\section{REFERENCES}

Attardi, G., Aloni, Y., Attardi, B., Ojala, D., Pica-Mattoccia, L., Robbertson, D. L. \& Storrie, B. (1970). Transcription of mitochondrial DNA in HeLa cells. Cold Spring Harbor Symposia on Quantitative Biology 35, 599-619.

Borst, P. (1972). Mitochondrial nucleic acids. Annual Review of Biochemistry 4r, 333-376.

Braly, P., Simpson, L. \& KRETZER, F. (I974). Isolation of kinetoplast-mitochondrial complexes from Leishmania tarentolae. Journal of Protozoology 21, 782-790.

Bresslau, E. \& SCremin, L. (1924). Die Kerne der Trypanosomen und ihr Verhalten zur Nuclealreaktion. Archiv für Protistenkunde 48, 509-5I5.

DubuY, H. G., MATTERN, C. F. \& RILEY, F. L. (1965). Isolation and characterization of DNA from kinetoplasts of Leishmania enriettii. Science $147,754-756$.

Hill, G. C. \& WhITE, D. W. (I968). Respiratory pigments of Crithidia fasciculata. Journal of Bacteriology 95, 2 I 5 I-2 I 57.

Kallinikova, V.D. (1969). Functional value of trypanosomatid kinetoplast in the light of cytochemical investigations. In Progress in Protozoology, IIIrd International Congress on Protozoology, pp. 31-32.

KIDDER, G. W. \& DuTTA, B. N. (1958). The growth and nutrition of Crithidia fasciculata. Journal of General Microbiology 18, 621-635.

KING, T. W. (1967). Preparation of succinate dehydrogenase and reconstitution of succinate oxidase. Methods in Enzymology ro, 322-331.

KIRBY, K. S. (1965). Isolation and characterization of ribosomal ribonucleic acids. Biochemical Journal 96, 266-269.

Kusel, J. P. \& STOREY, B. T. (1972). Evidence for the presence of two phosphorylation sites in mitochondria isolated from the trypanosomatid hemoflagellate, Crithidia fasciculata. Biochemical and Biophysical Research Communications 46, 501-507.

LANGDON, R. (1966). Glucose-6-phosphate dehydrogenase from erythrocytes. Methods in Enzymology 9, I 26-I3I.

LOENING, U. (1967). The fractionation of high-molecular-weight ribonucleic acid by polyacrylamide-gel electrophoresis. Biochemical Journal 102, 25 I-257.

LOENING, U. (1969). The determination of the molecular weight of ribonucleic acid by polyacrylamide gel electrophoresis. The effects of changes in conformation. Biochemical Journal 1r3, 131-138.

Lowry, O. H., Rosebrough, N. J., FarR, A. L. \& Randall, R. J. (195I). Protein measurement with the Folin phenol reagent. Journal of Biological Chemistry 193, 265-275.

MANCILla, R. \& NÁQUIRA, C. (1964). Comparative metabolism of "C-glucose in two strains of Trypanosoma cruzi. Journal of Protozoology 11, 509-513. 
Ozekr, Y., SooksRi, V., ONo, T. \& INOKI, S. (197I). Studies on the ultrastructure of kinetoplasts of Trypanosoma cruzi and Trypanosoma gambiense by autoradiography and enzymatic digestion. Biken's Journal I4, 97-118.

PACE, N. R. (1973). Structure and synthesis of ribosomal ribonucleic acid of prokaryotes. Bacteriological Reviews 37, 562-603.

PARISH, J. H. \& KIRBY, K. S. (1966). Reagents which reduce interactions between ribosomal RNA and rapidly labelled RNA. Biochimica et biophysica acta 129, 554-562.

Paulin, J. J. (1975). The chondriome of selected trypanosomatids. A three-dimensional study based on serial thick sections and high voltage electron microscopy. Journal of Cell Biology 66, 404-413.

RENGer, H. \& WolstenHOLme, D. (1970). Kinetoplast deoxyribonucleic acid of the hemoflagellate Trypanosoma lewisi. Journal of Cell Biology 47, 689-702.

RENGer, H. \& Wolstenholme, D. (1972). The form and structure of kinetoplast DNA of Crithidia. Journal of Cell Biology 54, 346-364.

Reinnders, L., Sloof, P., Sival, J. \& Borst, P. (1973). Gel electrophoresis of RNA under denaturing conditions. Biochimica et biophysica acta 324, 320-333.

Schildkraut, C. L., Marmur, J. \& Doty, P. (1962). Determination of the base composition of deoxyribonucleic acid from its buoyant density in $\mathrm{CsCl}$. Journal of Molecular Biology 4, 430-443.

Simpson, L. (1968). Behaviour of kinetoplast of Leishmania tarentolae upon cell rupture. Journal of Protozoology 15, 132-136.

Simpson, L. (1972). The kinetoplast of the hemoffagellates. International Review of Cytology 32, $139-207$.

Simpson, L. (1973). Structure and function of kinetoplast DNA. Journal of Protozoology 20, 2-8.

Simpson, L. \& LASKY, L. (1975). Kinetoplast messenger RNA's. Journal of Cell Biology 67, 402 a.

SPENCER, R. \& CROSs, G. A. M. (I976). Lability of RNA from the large cytoplasmic ribosomal subunit of the protozoon Crithidia oncopelti. Journal of General Microbiology 93, 82-88.

Steinert, M. (1960). Mitochondria associated with the kinetonucleus of Trypanosoma mega. Journal of Biophysical and Biochemical Cytology 8, 542-546.

Steinert, M. \& VAN Assel, S. (1975). L'ADN mitochondrial de Crithidia. Journal of Protozoology 22, $85 a$.

Steinert, G., Firket, H. \& Steinert, M. (1958). Synthèse d'acide désoxyribonucléique dans le corps parabasal de Trypanosoma mega. Experimental Cell Research 15, 632-635.

Steinert, M., VAN Assel, S. \& STEnNert, G. (I969). Etude, par autoradiographie, des effets du bromure d'éthidium sur la synthèse des acides nucléiques de Crithidia luciliae. Experimental Cell Research 56, 69-74.

SZYBALSKI, W. (1968). Equilibrium sedimentation of viruses, nucleic acids and other macromolecules in density gradients. Fractions $1,1-15$, Beckman Instruments Inc.

TONER, J. J. \& WEBER, M. M. (I972). Respiratory control in mitochondria from Crithidia fasciculata. Biochemical and Biophysical Research Communications 46, 652-660.

Vesco, C. \& Penman, S. (1969). The cytoplasmic RNA of HeLa cells: new discrete species associated with mitochondria. Proceedings of the National Academy of Sciences of the United States of America 62, $218-225$. 